\title{
The Immunological Reactivity and Biological Activity of Synthetic Glucagon
}

\author{
K. F. WeInges*, E. WÜnsch**, G. Biro, H. Kettu and M. Mitzuno \\ Ir. Medizinische Klinik und Poliklinik der Universität des Saarlandes in Homburg/Saar \\ Received: July 3, 1968
}

Summary. Synthetic glucagon (nonicosapeptide) appears to be identical with the natural hormone in chemical analyses, and has a similar crystalline structure. Synthetic glucagon has the same biological activity as the natural, twice recrystallized, pancreatic glucagon when measured by its effects on glycogenolysis in the liver, on lipolysis in adipose tissue and on endogenous insulin release. In immunological tests both the synthetic nonicosapeptide and pentadecapeptide $9-23$ showed identical immunoreactivity to the natural hormone. Proof of the total synthesis of glucagon appears conclusive.

La réactivité immunologique et l'activité biologique du glucagon synthétique

Résumé. D'après l'analyse chimique, le glucagon obtenu par préparation synthétique (Nonicosapeptide) montre une similitude frappante avec l'hormone naturelle et a une structure cristalline semblable. Le glucagon synthétique possède la même activité biologique que le glucagon naturel (deux fois cristallisé) provenant de l'extrait pancréatique, lorsque ses effets sont mesurés sur la glycogénolyse des coupes de foie isolé, sur la lipolyse in vitro du tissu adipeux, ainsi que sur la glycémie humaine et la sécrétion insulinique endogène. L'hormone synthétique nonicosapeptide ainsi que le pentadecapeptide de l'hormone séquence $9-23$ montrent dans les tests immunologiques une immuno-réactivité identique à celle de l'hormone naturelle. La réussite de la synthèse complète du glucagon pancréatique est ainsi démontrée.

Immunologisches Realtionsvermögen und biologische Aktivität des synthetischen Glucagons

Zusahoueqfassung. Das synthetisch hergestellte Glucagon (Nonikosapeptid) zeigt in den chomischen Analysen eine weitgehende Identität mit dem natürlichen Hormon und bildet die gleiche Kristallform. Die vergleichenden biologischen Untersuchungen in vitro und in vivo zeigten, daB das synthetische Glucagon eine ähnliche Aktivität wie das aus Pankreasextrakten gewonnene zweifach rekristallisierte Glucagon besitzt. Es wurde die Wirkung auf die Glycogenolyse an isolierten Leberschnitten und auf die Lipolyse an isolierten Fettzellen in vitro sowie auf den Blutzucker und auf die endogene Insulinsekretion in vivo beim Menschen gemessen. Im immunologischen Test zeigte nicht nur das synthetisch hergestellte Nonicosapeptid, sondern auch das Pentadecapeptid der Hormon-Sequenz 9-23 eine dem natürlichen Hormon vergleichbare Reaktionsfähigkeit. Es ist somit der Beweis erbracht, daß die Totalsynthese des Pankreashormons Glucagon gelungen ist.

Key-words: Glucagon; natural and synthetic hormone, glycogenolysis, lipolysis, blood glucose, endogenous insulin, immunoreactivity.
Both the molecular structure and physiological role of glucagon have become known in considerable detail by chemical, biochemical, biological and immunological methods [9]. STAus and his co-workers [6] isolated, in 1953 , this biologically active oligopeptide from raw insulin preparations. Bromer and his co workers [1] were the first to propose its primary structure in 1956 :

$$
\begin{aligned}
& \mathrm{H}_{2} \mathrm{~N}-\mathrm{His}-\mathrm{Ser}-\mathrm{GH}_{2}-\mathrm{Gly}-\mathrm{Thr}-\mathrm{Phe}-\mathrm{Th} \mathrm{r}-\mathrm{Ser}- \\
& \underset{9}{\operatorname{Asp}}-\underset{10}{\mathrm{Tyr}}-\underset{11}{\mathrm{Ser}}-\underset{12}{\mathrm{Lys}}-\underset{13}{\mathrm{Tyr}}-\underset{14}{\mathrm{Leu}}-\underset{15}{\mathrm{Asp}}-\underset{16}{\mathrm{~A} e r}-\underset{17}{\mathrm{Arg}}- \\
& \mathrm{Arg} \text {-Ala-Glu-Asp - Phe-Val-Glu-Try-Leu- }
\end{aligned}
$$

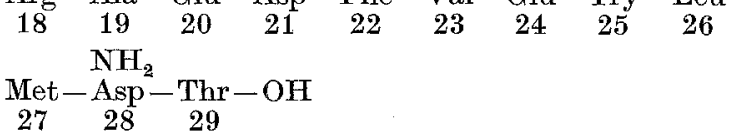

The synthesis of glucagon was achieved by WÜNSCH et al. [12, 13] in 1967 (Fig. 1):

* This study was supported by a grant from the "Deutsche Forschungsgemeinschaft".

** Max-Planck-Institut für Eiweiß und Lederforschung, Abteilung für Peptidchemio, München.
The synthetic nonicosapeptide $1-29$ a was crystallized by leaving a $0.25 \%$ aqueous solution near the isoelectric point at $4^{\circ} \mathrm{C}$ for several days, whereupon rhombic dodecahedron crystals slowly predipitated (Fig. 2).

(The synthetic hormone was completely dissolved by adjusting an aqueous suspension of the hormone to pH 10.8 using $0.05 \mathrm{~N}$ sodium hydroxide, then changing to $\mathrm{pH} 9.3$ using $0.05 \mathrm{~N}$ hydrochloric acid.)

Trypsin degradation of both the natural glucagon and the fully synthetized tricosapeptide $1-23$ led to similar fractions in the "alkali zone". Identical amounts of free arginine were found, a fact which is due to an arginyl-arginyl bond in the sequence.

The identity of both biological activity and immunological reactivity, were crucial criteria to prove that total synthesis of glucagon and the amino acid sequence as proposed by BRoMER and co-workers [1] were correct. To study these biological properties of the synthetic hormone, the effect of crystallized synthetic glucagon was compared with the effect of twice recrystallized natural pork glucagon ${ }^{1}$ as shown in the following tests [11]:

\footnotetext{
1 Kindly supplied by Dr. SoнöNw, Farbwerke Hoechst, Frankfurt-Hoechst.
} 
1. glycogenolysis in slices of rat liver in vitro [7];

2. lipolysis in isolated fat cells [4] (epididymal fat pad of rat) measuring the release of glycerol and free fatty acids $[10]$

3. measurement in vitro of ${ }^{14} \mathrm{CO}_{2}$ production from ${ }^{4} \mathrm{C}$-6-glucose in isolated fat cells $[10]$;
In the biological tests hormone concentrations between 0.005 and $1 \mu \mathrm{g} / \mathrm{ml}$ were used. Glucose (hexokinase method, Boehringer) and glycerol [3] were determined enzymatically, free fatty acids according to DowE [2], and plasma insulin radioimmunologically [14].

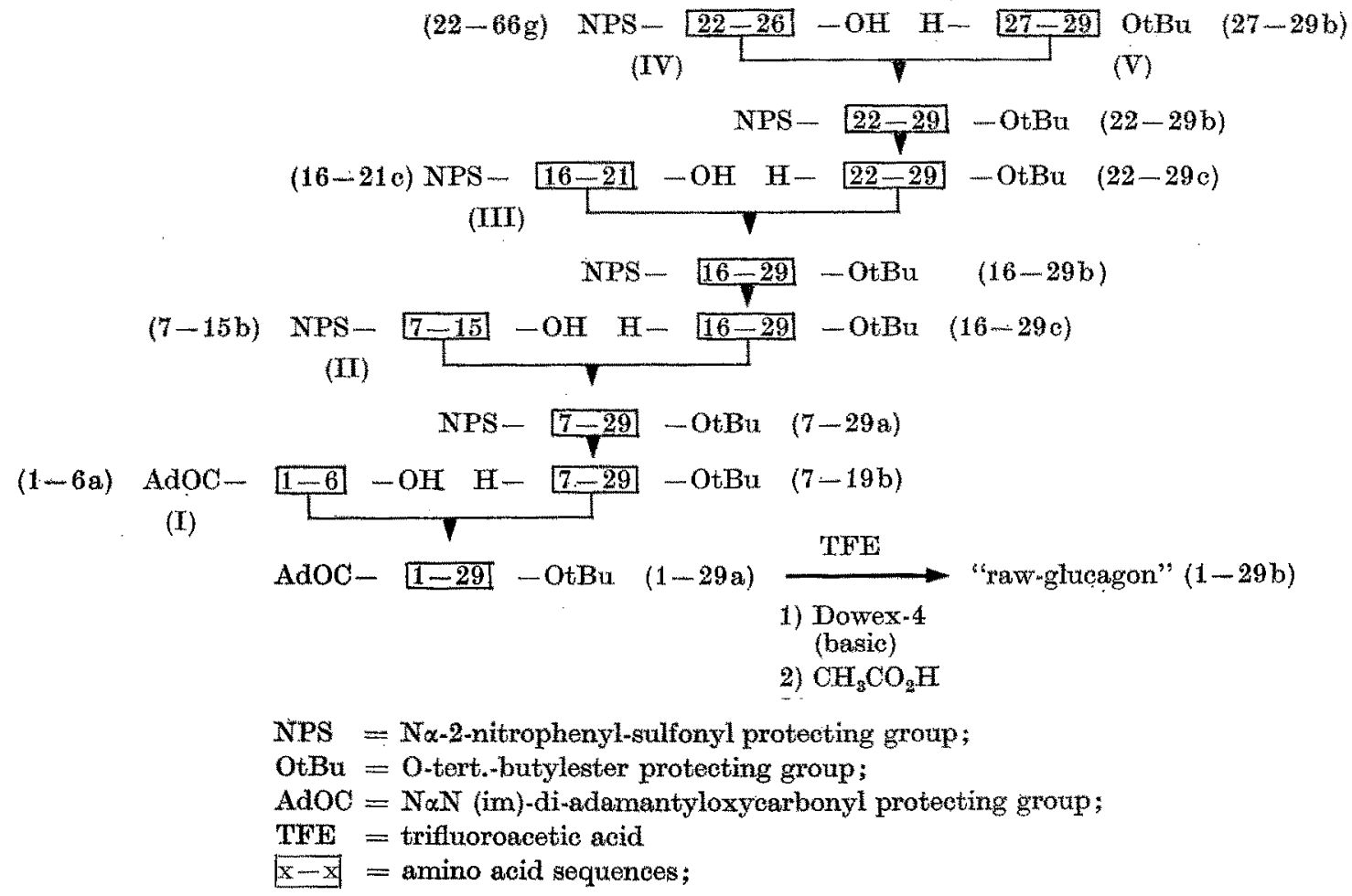

Fig. 1. Scheme of glucagon synthesis [12]

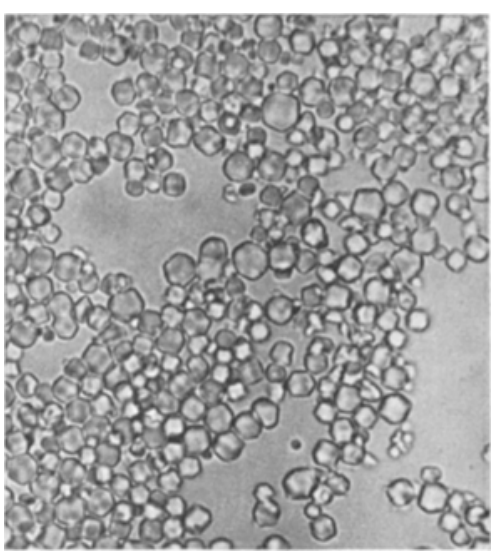

Fig. 2. Orystals of synthetio glucagon [13]

4. the changes of blood glucose and plasma insulin level in human subjects after intravenous injections of $1 \mathrm{mg}$ glucagon in $10 \mathrm{ml} 0.9 \mathrm{~N} \mathrm{NaCl}$ [5];

5. radioimmunologioal measurement of reactivity with anti-glucagon-serum from rabbits (final dilation $1: 200)[8,9]$.
Results and Discussion

In liver slices both synthetic and natural glueagon caused a strong glycogenolysis depending on the concentration of the hormone; $0.1 \mu \mathrm{g}$ glucagon $/ \mathrm{ml}$ released about 6 umol of glucose/ml/100 $\mathrm{mg}$ liver dry weight. At $1.0 \mu \mathrm{g}$ glucagon $/ \mathrm{ml}$ the glucose concentration in the incubated medium increased twofold within $60 \mathrm{~min}$. There was no significant difference between the synthetic and the natural glucagon, as can be seen in Fig. 3 . When measuring the lipolysis in isolated fat cells the synthetic glucagon had an effect comparable with the uatural hormone (Fig. 4). At a concentration of $0.005 \mu \mathrm{g}$ glucagon/ml there was already a significant release of glycerol and free fatty acids into the incubation medium. A very distinct rise of the release was noticed at increased hormone concentrations of 0.05 and $0.5 \mu g$ ) $\mathrm{ml}$. Earlier investigations [10] had shown that fat cells take up more glucose during a hormone-induced lipolysis, and that glycolysis and glucose oxidation, especially at the 6 th C atom of glucose, are also accelerated. The increased glucose metabolism in adipose tissue corresponds to the extent of lipolysis as shown in the 
measurement of ${ }^{14} \mathrm{CO}_{2}$-production out of ${ }^{14} \mathrm{C}-6$-glueose (Fig. 5). Here again no difference was found between natural and synthetic glucagon in its effect on lipolysis.

After i. $v$, injection of $1 \mathrm{mg}$ crystallized synthetic glucagon the rise of blood sugar in man is comparable

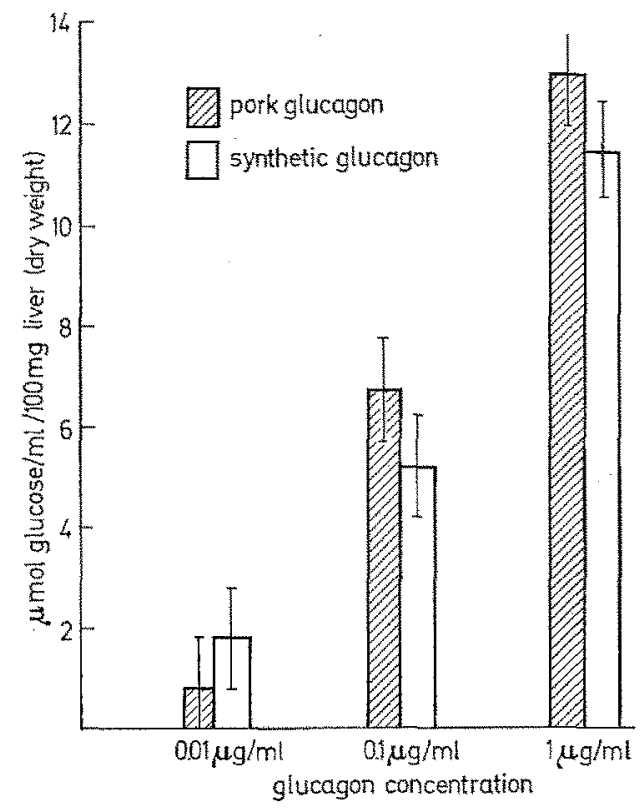

Fig. 3. Fffect of synthetic or natural glueagon on glucoseoutput (glycogenolysis) from rat liver slices in vitro $(n=4 ;$ mean values \pm se.e.m.
Crystallized synthetic glucagon displaced ${ }^{131}$ iodinelabelled glucagon from the antibody binding to a similar extent as the unlabelled natural hormone. With rising hormone concentrations the two standard curves show a parallel decrease of the activity of the hormone-

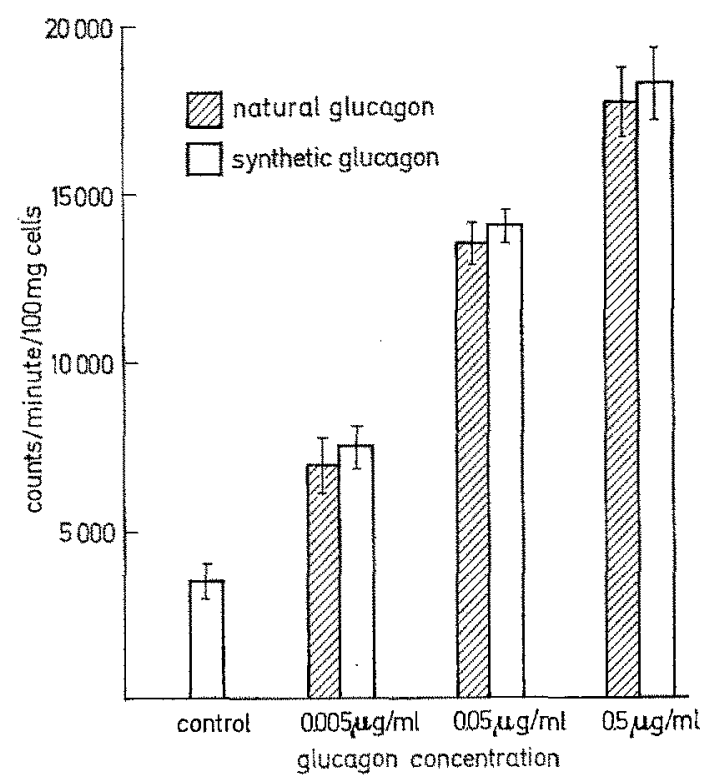

Fig. 5. Effect of synthetic or natural glueagon upon glucose-6. ${ }^{14} \mathrm{C}$ incorporation into $\mathrm{CO}_{2}$ by isolated rat fat cells $(n=4$; mean values $\perp$ s. e.m. $)$

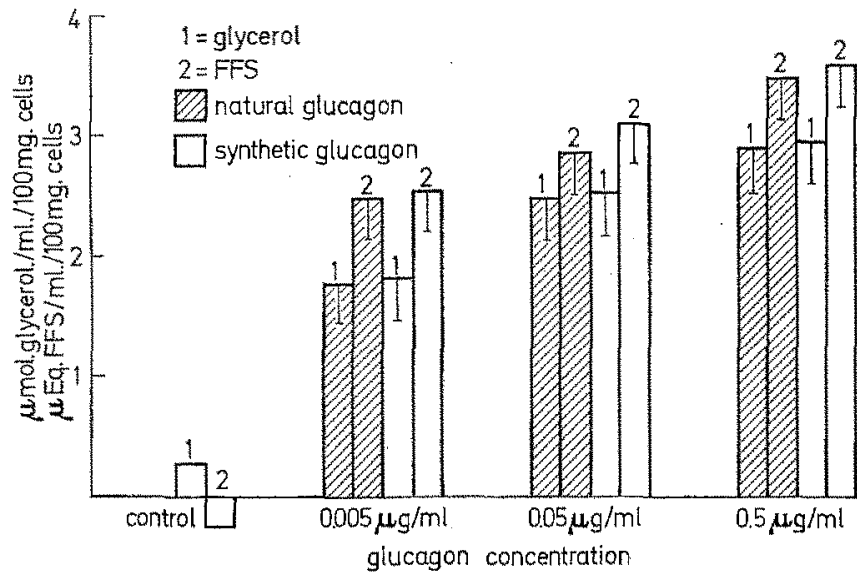

Fig. 4. Effect of synthetic or natural glucagon on the release of glycerol and free fatty aeid (FFS) from isolated rat fat cells $(n=4$; mean values \pm s.e.m. $)$

with that obtained by natural glucagon (Fig. 6). Within 5 min after the injection a significant rise in plasma insulin was also noticed. This rise was not due to an increase in blood sugar, but the consequence of a direct stimalation of synthetic glucagon on endogenous release of insulin $[9,5]$.

A reaction of immunological identity of synthetio and natural glucagons with anti-glucagon-serum from rabbits was also observed (Fig. 7 ).

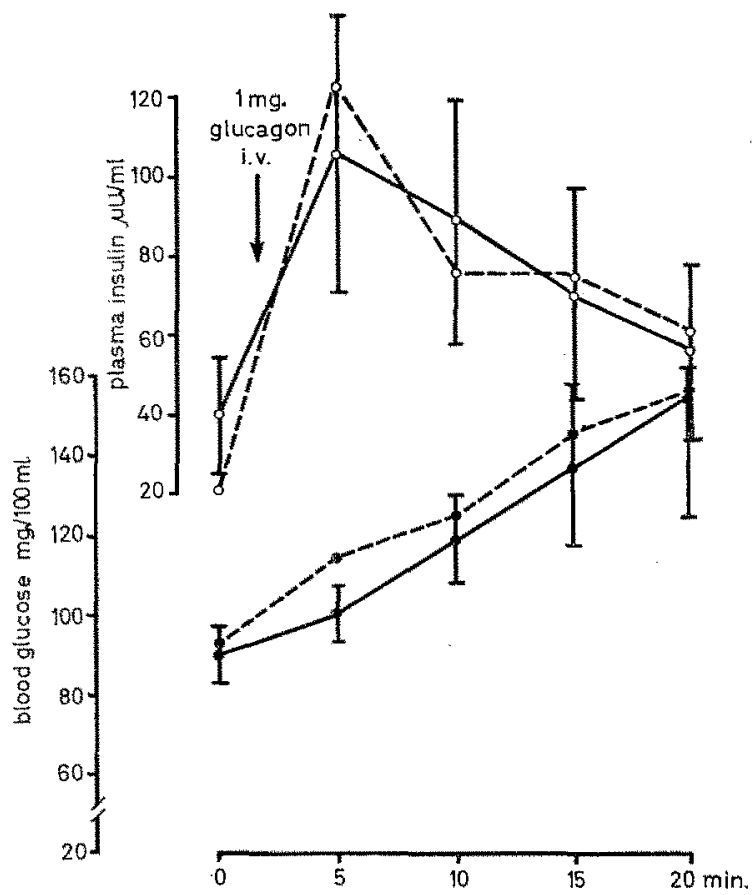

Fig. 6. Blood glucose and plasma insulin response to i.v. injection of $1 \mathrm{mg}$ synthetic (-) or natural (- glucagon into human subjects 
antibody complex. It could be further demonstrated that the synthetic pentadecapeptide $9-23 \mathrm{~b}$ with the hormone sequence $9-23$ has the full immunoreactivity but no biological activity of glucagon ${ }^{2}$.

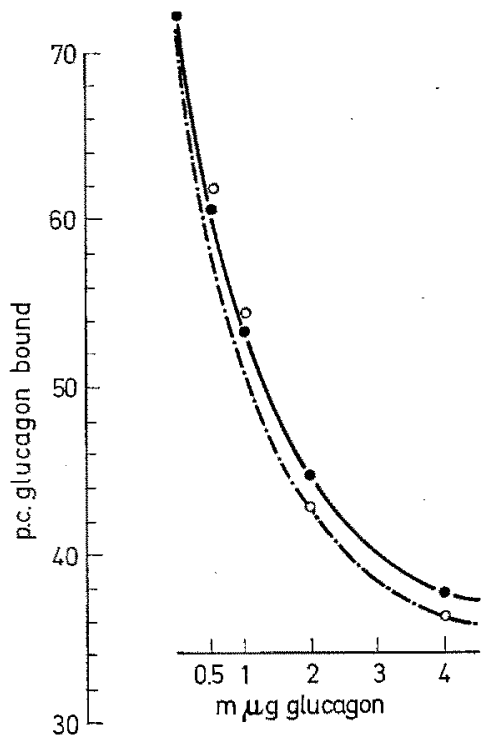

Fig. 7. Comparison of immunoreactivity of synthetic or natural glueagon with anti-pork glucagon serum from rabbits

\section{References}

1. Bromer, W.W., L.G. Srnt, A. Staub, and O.K. Bemades: The amino acid sequence of glucagon. J. Amer. chem. Soc. 78, 3858-3860 (1956).

2. Doue, V.P.: A relation between non-esterified fatty acids in plasma and the motabolism of glucose. $J$. clin. Invest. 35, $150-154(1956)$.

3. Gartand, P.B., and P.J. Randre: A rapid enzy.

2 These immunological tests were carried out by Drs. Rossmin and Assay from the Institut National de la Santé et de la Recherche Médicale Groupe de Recherche de Diabétologie et d'Etudes des Hormones Protéiques Paris. matic assay for glycerol. Nature (Lond.) 196, 987-988 (1962).

4. RodBelL, M.: Metabolism of isolated fat cells. I. Effects of hormones on glucose metabolism and lipolysis. J. biol. Chem. 239, 375-380 (1964).

5. Samols, E., G. MaORI, and V. MaRks: Interrelationship of glucagon, insulin and glucose. The insulinogenie effect of glucagon. Diabetes 15, 855-866 (1966).

6. Staub, A., L. SinN, and O.K. Berrens: Purification and crystallization of hyperglycomio-glycogenolytie factor (HGF). Scionce 117, $628-629$ (1953).

7. Tybmigmen, J.M., and R.H. Winliams: Assay for glucagon in rabbit plasma. Metabolism 7, 635-645 (1958).

8. Uxagr, R.H., A.M. Eismintraut, M.S. MoCart, S. KetLer, and H.C. LANZ: Glucagon antibodies and their use for immunoassay for glucagon. Proc. Soc. exp. Biol. (N.Y.) 1102, 621-623 (1959).

9. Wernges, K. F.: Glucagon, Monographie in der Reihe Biochemie und Klinik, Hrsgb. G. Wertzer $u$. N. ZöLLNER. Stuttgart: Thieme-Verlag, 1968.

10. - Fettsäure- und Glucosestoffwechsel am Fettgewebe unter den Bedingungen der hormonsensitiven Lipolyse. In: Die Pathogenese des Diabetes mellitus. Die endokrine Regulation des Fettstoffwechsels. Springer: Berlin 1967.

11. - Untersuchungen der biologischen Aktivität und immunologischen Reaktionsfähigkeit von synthetischen Glucagon. 14. Symposion Deutsche Ges. Endokrinologie, Heidelberg, $7 .-9.3 .1968$. Über Nebenschilddrüse und endokrine Regulation des Calziuna. stoffwechsels, Spontan-Hypoglykämie-Glucagon. Springer: Berlin 1968. Druck).

12. WÜNsor, E.: Die Totalsynthese des Pankreas-Hormons Glueagon. Z. Naturforseh. 22 b, 1269-2862 (1967).

13. - Die Totalsynthese des Pankreashormons Glucagon. Habilitationssohrift (Max Planck-Institut für Eiweiß und Lederforsehung, Abtlg. f. Peptidchemie, München) für das Fachgebiet Organische Chemie. München: Techn. Hochschule 1967.

14. YALOW, R.S., and S.A. Berson: Immunoassay of endogenous plasma insulin in man. J. clin. Invest. 39, $1157-1175(1960)$.

Professor Dr. K.F. Wemaes II. Medizinische Klinik und Poliklinik der Universität des Saarlandes 6650 Homburg/Saar 